\title{
PART OF THE Climate
}





\section{PART \\ OF THE \\ CLIMATE \\ American \\ Cubist Poetry}

Jacqueline Vaught Brogan

Berkeley Los Angeles Oxford 
University of California Press

Berkeley and Los Angeles, California

University of California Press

Oxford, England

Copyright $(1991$ by The Regents of the University of California

Library of Congress Cataloging-in-Publication Data

Brogan, Jacqueline Vaught, 1952-

Part of the climate : cubism and twentieth-century American

poetry / Jacqueline Vaught Brogan.

p. $\quad \mathrm{cm}$.

Includes bibliographical references.

ISBN 0.520.06848.3 (alk. paper)

1. American poetry -20 th century-History and criticism. 2. Art and literature - United States - History -20 th century. 3. Cubism and literature-United States. I. Title

PS310.A76B7 1990

$90 \cdot 34743$

$811^{\prime} .52091-\mathrm{dc} 20$

CIP

Printed in the United States of America

The paper used in this publication meets the minimum requirements of American National Standard for Information Sciences-Permanence of Paper for Printed Library Materials, ANSI Z39.48-1984

This book is a print-on-demand volume. It is manufactured using toner in place of ink. Type and images may be less sharp than the same material seen in traditionally printed University of California Press editions. 